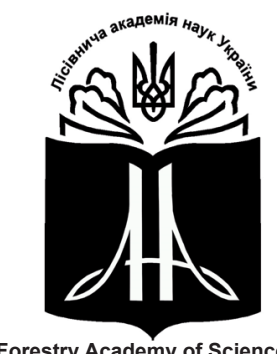

Forestry Academy of Sciences of Ukraine

Наукові праці Лісівничої академії наук України Proceedings of the Forestry Academy of Sciences of Ukraine

http://fasu.nltu.edu.ua

https://doi.org/ 411708

Article received 2017.10.04

Article accepted 2017.11.15
ISSN 1991-606X print

ISSN 2616-5015 online

(a) $\triangle$ Correspondence author

Svitlana Los

svitlana_los@ukr.net

УДК $630.5: 165.6: 674.031: 632.264$

\title{
Динаміка репродуктивних процесів на клонових насінних плантаціях дуба звичайного (Quercus robur L.) у Лівобережному Лісостепу України
}

\author{
С. А. Лось ${ }^{1}$
}

Проаналізовано дані 18-річних спостережень за інтенсивністю ивітіння та плодоношення клонів дуба звичайного (Quеrcus robur L.) та їхніх груп на двох КНП у Харківській області, створених у 1979 та 1985 рр. за однаковою технологією. Підтверджено доиільність використання запропонованого раніше підходу до розподілу клонів на групи за інтенсивністю плодоношення. Виявлено значущі відмінності між середніми показниками плодоношення груп клонів, при ц̧ьому різниця між групами мінімальна в неврожайні роки і максимальна-у роки з рясним урожаєм.

Виявлено синхронність динаміки репродукиійних процесів на різних КНП Харківської області. В окремі роки інтенсивність ичвітіння на КНП у Кочетоцькому лісництві на багатших трунтах була вищою, ніж на КНП у Південному лісництві. Цвітіння і плодоношення групи клонів з інтенсивним і середнім плодоношенням на обох КНП упродовж 18 років спостережень стабільно були вищими, ніж групи клонів з низьким плодоношенням та нещеплених дерев.

Підтверджено, щзо для дуба звичайного інтенсивність репродукції є не менш важливим показником, ніж прямизна стовбура та інтенсивність росту, який має бути одним із пріоритетних під час відбору плюсових дерев. Наголошено, щзо використання для створення КНП дуба звичайного клонів з низькою інтенсивністю репродукиії може мати такий самий ефект, як і використання нещеелених дерев. Рекомендовано створювати КНП лише із клонів, які характеризуються середнім і рясним плодоношенням, при иььому перевагу варто надавати останнім.

Ключові слова: інтенсивність ц̧вітіння і плодоношення, репродукиія, репродуктивна спроможність, клони, плюсові дерева, клонові насінні плантаціï, Quеrсus robur L.

Вступ. Клонові насінні плантації (КНП), які забезпечують лісогосподарське виробництво покращеним або елітним насінням, нині залишаються найважливішими об'єктами лісонасінної бази в багатьох країнах світу (Review of the Swedish tree breeding programme, 2011; Oweviev. Forest Tree Breeding Center, 2013 Improving seed production from forest seed orchards, 2013; Los, 2013; IUFRO Seed orchard conference, 2017). Так, у Швеції на КНП нині заготовляють $62 \%$ насіння ялини європейської (Picea abies L.) та $94 \%$ сосни звичайної
(Pinus sylvestris L.) від загальної кількості заготовленого (IUFRO Seed orchard conference, 2017). У США, в штаті Північна Кароліна, 98\% насіння сосни ладанної (Pinus taeda L.) отримують 3 КНП, при цьому за останні 10 років річний обсяг вирощування півсібсових сіянців зріс від 26,5 до 116,3 млн шт. (Steve McKeand, 2017). В Україні, на об'єктах постійної лісонасінної бази (ПЛНБ), у 2016 р. заготовлено 33,0\% насіння, зокрема, насіння хвойних порід - 25,5\%, жолудів дуба звичайного $-45 \%$ (Yurkiv, 2016).

\footnotetext{
Лось Світлана Анатоліївна - член-кореспондент Лісівничої академії наук України, кандидат сільськогосподарських наук, завідувач лабораторії селекції. Український науково-дослідний інститут лісового господарства та агролісомеліорації ім. Г. М. Висоцького, вул. Пушкінська, 86, м. Харків, 61024, Україна. Тел.: 057-707-80-77, +38-097-138-97-92. E-mail: svitlana_los@ukr.net
} 
3 іншого боку, в середовищі українських лісових експертів та науковців останнім часом звучать думки щодо відсутності перспектив плантаційного насінництва. Однією із причин певного розчарування у насінництві на основі КНП $є$ низькі урожаї насіння (Bilous, 2004). Вирішення цієї проблеми C. С. П'ятницький (Pyatnitsky, 1951) вбачав у проведенні заходів боротьби зі шкідниками. Такої ж думки притримувався і В.І. Білоус (Belous, 1980, Bilous, 2004). Новий поштовх розвитку насінництва може надати «нова клоново-плантаційна концепція» (new seed orchard concept - NSOC), запропонована китайськими науковцями, і яка полягає у зменшенні площ плантацій до 6-10 га для зручнішого господарювання, формування крон і підтримування висоти останніх до 3,5 м, а також у залученні лише тих клонів, які добре схрещуються між собою, виборі ділянок із сприятливими умовами для рослин та внесенні добрив (Zhenxiang, 2017).

Останнім часом в Україні, у ході виконання «Програми розвитку лісонасінної справи на 2010-2015 роки» (Program for the seed growing development to 2010-2015, 2010), активно виконують роботи з відбору плюсових дерев та створення нових КНП головних лісотвірних порід. У цій ситуації дуже важливо не повторювати помилок минулого, які зумовили низьку ефективність деяких сучасних КНП (Biloys, 2004). Так, у чинних нині Настановах $з$ лісового насінництва (Guidelines for forest seed growing, 1993), які регламентують відбір плюсових дерев та створення КНП, не враховано репродуктивну спроможність плюсових дерев та їх клонів, хоча цей показник $€$ не менш важливим, ніж якість стовбура та інтенсивність росту. 3 огляду на те, що цільове призначення клонових насінних плантацій - забезпечення лісового господарства покращеним насінням, збереження та відтворення цінного генофонду лісів - найважливішим показником, що характеризує ефективність насінної плантації, є інтенсивність репродукції представлених на ній клонів плюсових дерев.

Репродуктивні особливості клонів дуба звичайного на КНП Харківської обл. досліджують протягом тривалого періоду. У наших попередніх дослідженнях не виявлено істотних відмінностей між показниками інтенсивності цвітіння і плодоношення клонів різних фенологічних груп (Los, 2010). 3 іншого боку, підтверджено генетичну зумовленість репродуктивної здатності клонів. Встановлено, що амплітуда коливань інтенсивності плодоношення найбільша у клонів, які інтенсивно плодоносять, і найменша - у клонів із стабільно слабким плодоношенням, але врожайні та неврожайні роки збігаються, тобто на сприятливі умови група клонів 3 інтенсивним плодоношенням реагує кращим плодоношенням, ніж клони інших груп. Клони зі слабким плодоношенням навіть у сприятливі роки дають мінімальний урожай (Los, 2008). Результати, що підтверджують генетичну зумовленість репродуктивної спроможності клонів дуба, отримали також й інші дослідники. Так, за даними В.С. Феннича (Fennytch, 2006), не усі клони та дерева на КНП дуба в Закарпатті однаковою мірою брали участь у формуванні врожаю на плантації. Розглядаючи особливості репродукції клонів на КНП Quercus acutissima, корейські науковці (Hyun-Tae Kima et al., 2016) виявили мінливість клонів за урожайністю жолудів і мінливість плодоношення за роками та наголосили на важливості доброго освітлення крон для формування репродуктивних органів.

Об'єкти та методика досліджень. Об'єкт дослідження - клонові насінні плантації дуба звичайного (Quercus robur L.).

Предмет дослідження - репродукція клонів на клонових насінних плантаціях дуба звичайного.

Мета досліджень - встановити особливості репродукції дуба звичайного на КНП на основі порівняння показників інтенсивності цвітіння і плодоношення різних клонів, їх груп та КНП у Лівобережному Лісостепу України.

Дослідження проводили на двох КНП у Харківській обл., створених садінням щеплених саджанців із закритою кореневою системою. Схема розташування щеплених рослин - 10 х 5 м. Така відстань між рослинами забезпечує добру освітленість крон рамет. Першу КНП було створено у 1979 р. у кв. 129 Південного лісництва ДП «Харківська ЛНДС» в умовах $\mathrm{D}_{2}$ на сірих лісових суглинках (рис. $1, \mathrm{~A}$ ). Тут представлено 54 клони плюсових дерев дуба звичайного, різних за інтенсивністю репродукції.

Другу КНП створено у 1985 р. у кв. 297 Кочетоцького лісництва ДП «Чугуєво-Бабчанське ЛГ» в умовах $\mathrm{D}_{2}$ на звичайних, середньо гумусних чорноземах (рис. 1, Б). Для ії створення Н.І. Давидова використала 20 клонів, частина 3 яких стабільно інтенсивно плодоносить, а інші характеризуються перемінним та середнім плодоношенням. Клони 3 низьким плодоношенням відсутні. Отже, гіпотезу про недоцільність використання під час створення КНП клонів з поганою репродукцією було сформульовано ще у 80-ті роки, однак не було відображено у наукових публікаціях.

Інтенсивність цвітіння та плодоношення клонів на КНП визначали візуально за шестибальною шкалою лабораторії селекції УкрНДІЛГА. Враховуючи, що у дуба звичайного зазвичай спостерігається збалансованість інтенсивності цвітіння жіночих i чоловічих суцвіть (Los, 2008), інтенсивність цвітіння чоловічих суцвіть у цій роботі не висвітлювали. Бальна оцінка інтенсивності плодоношення дає змогу здійснювати порівняльний аналіз за цим показником різних плантацій та рамет різного віку. Обліки інтенсивності цвітіння та плодоношення 14 клонів плюсових дерев дуба звичайного з Харківської (рис. 2) і Сумської областей, представлених на обох КНП (клони 1 і 2 груп), та 5 клонів, представлених лише на КНП 1979 р. (клони 3 групи), здійснювали впродовж 18 років (1999-2016 рр.) за 5-7 раметами кожного клону. У табл. 1 надано коротку інформацію щодо плюсових дерев дуба звичайного, клони яких досліджували. 

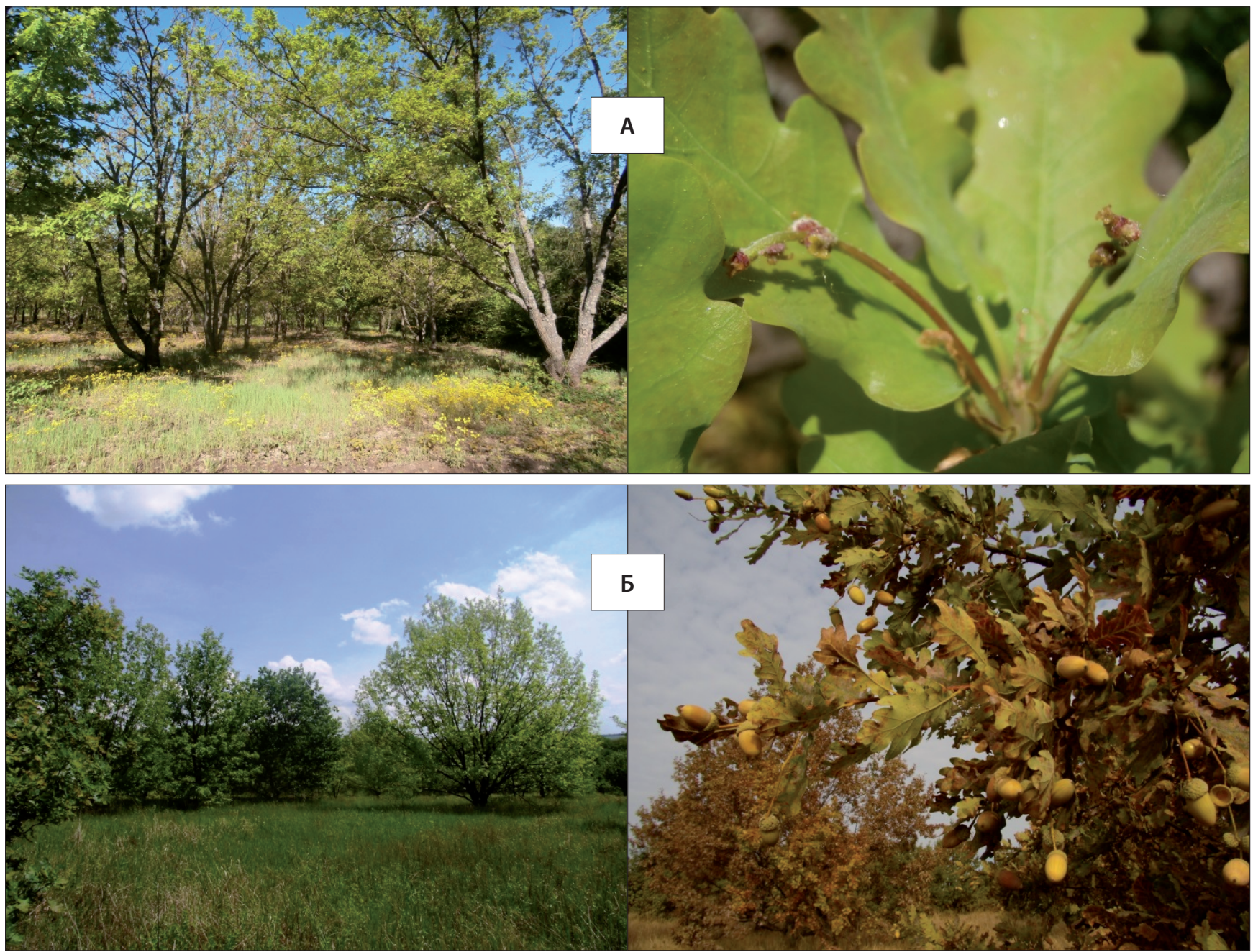

Рис. 1. КНП дуба звичайного у Південному лісництві Харківської ЛНДС (А, 2015 р.) та у Кочетоцькому лісництві ДП «Чугуєво-Бабчанське ЛГ», (Б, 2008 р.)
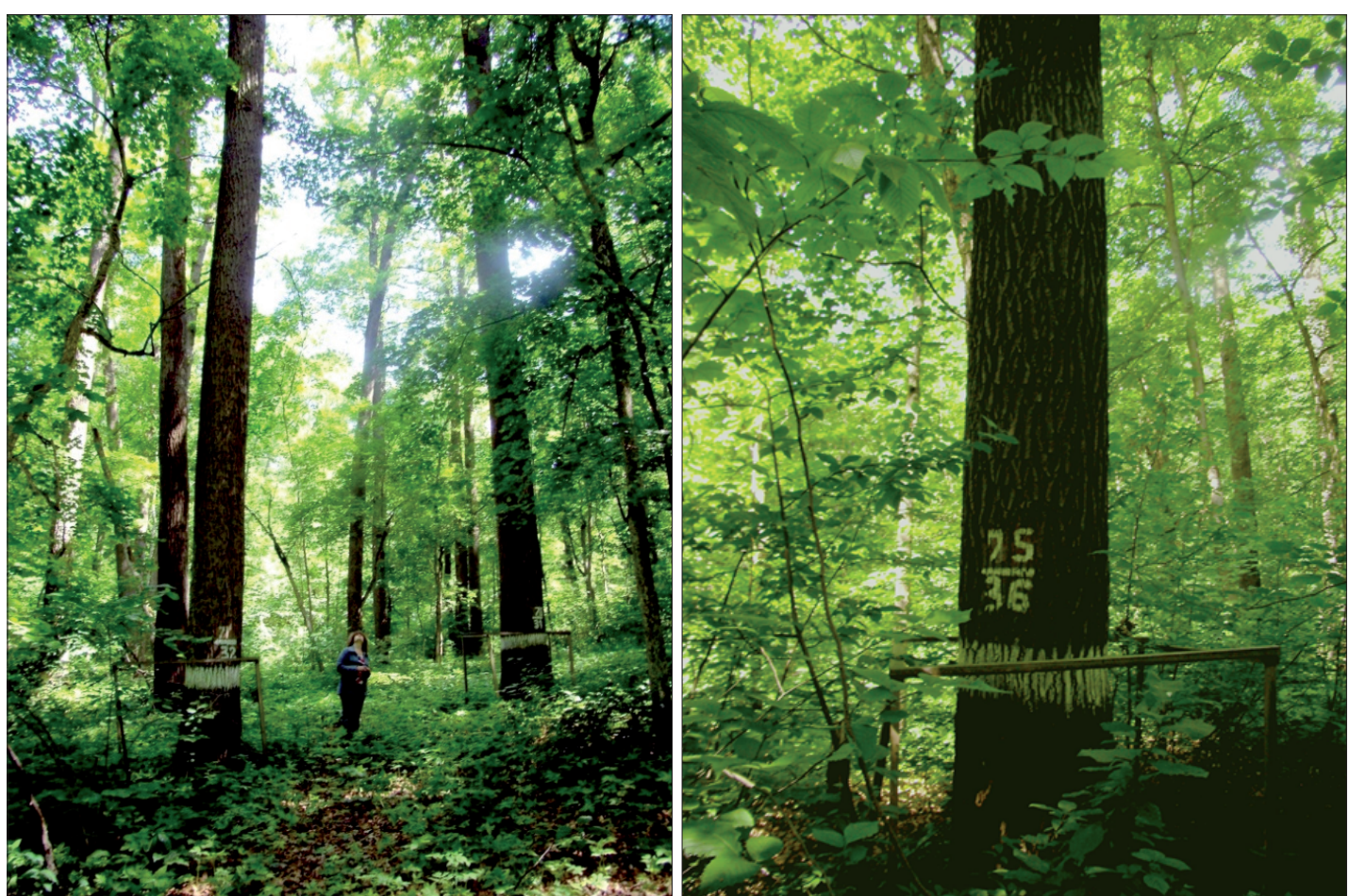

Рис. 2. Плюсові дерева дуба звичайного у Кочетоцькому лісництві ДП «Чугуєво-Бабчанське ЛГ» (червень, 2009 р) 
Коротка характеристика плюсових дерев дуба звичайного, представлених на КНП в Південному і Кочетоцькому лісництвах

\begin{tabular}{|c|c|c|c|c|}
\hline \multirow{2}{*}{$\begin{array}{l}\text { Шифр } \\
\text { клону }\end{array}$} & \multirow{2}{*}{$\begin{array}{c}\text { № ПД за } \\
\text { Держреєстром }\end{array}$} & \multicolumn{2}{|c|}{ Місце розміщення плюсового дерева } & \multirow{2}{*}{$\begin{array}{c}\text { Група за інтенсивністю } \\
\text { репродукції }\end{array}$} \\
\hline & & Лісове господарство & Лісництво, кв./вид. & \\
\hline Д- $3^{1}$ & 24 & Данилівське (нині ХЛНДС ) & Південне, 138/8 & 2 \\
\hline Д-5 & 26 & Данилівське (нині ХЛНДС ) & Південне, $138 / 8$ & 1 \\
\hline K-31 & 70 & Чугуєво-Бабчанське & Кочетоцьке, 209/5 & 1 \\
\hline K-33 & 72 & Чугуєво-Бабчанське & Кочетоцьке, 209/5 & 1 \\
\hline K-36 & 75 & Чугуєво-Бабчанське & Кочетоцьке, 209/5 & 2 \\
\hline Л-7 & 62 & Жовтневе & Люботинське, 23/1 & 3 \\
\hline Л-8 & 63 & Жовтневе & Люботинське, 23/1 & 3 \\
\hline$\Pi-8$ & 81 & Чугуєво-Бабчанське & Печенізьке, 45/2 & 2 \\
\hline$\Pi-14$ & 87 & Чугуєво-Бабчанське & Печенізьке, 45/2 & 3 \\
\hline$\Pi-20$ & 93 & Чугуєво-Бабчанське & Печенізьке, 45/2 & 1 \\
\hline П-21 & 94 & Чугуєво-Бабчанське & Печенізьке, 45/2 & 2 \\
\hline$\Pi-23$ & 96 & Чугуєво-Бабчанське & Печенізьке, 45/2 & 2 \\
\hline$\Pi-24$ & 97 & Чугуєво-Бабчанське & Печенізьке, 45/2 & 1 \\
\hline Сy-27 & $* 2$ & Сумське & Сумське & 3 \\
\hline Та-7 & $*$ & Зміївське & Таранівське (нині & 1 \\
\hline Ta-18 & $*$ & Зміївське & Гомільшанське) & 2 \\
\hline T€-5 & 102 & Чугуєво-Бабчанське & Тєтлєзьке, 121/2 & 2 \\
\hline Tp-15 & 86 & Тростянецьке & Нескучанське, 18/3 & 3 \\
\hline Ш-3 & $*$ & Гутянське & Шарівське, 28/6 & 2 \\
\hline
\end{tabular}

Примітка: ${ }^{1}$ шифр клону складається з першої літери назви лісництва або лісового господарства та номера плюсового дерева по господарству

2 *_плюсові дерева, вилучені з чинного Державного реєстру

Розподіл клонів на групи прийнято згідно з результатами наших попередніх досліджень (Los, 2008) $з$ деякими уточненнями.

1 група (клони з інтенсивним плодоношенням) - клони, в яких упродовж 9-10 років із 15 (60\% випадків) і більше середня інтенсивність плодоношення перевищувала 2,5 бала;

2 група (клони 3 середньою інтенсивністю плодоношення) - клони, в яких упродовж вказаного періоду (60\% випадків) і більше середня інтенсивність плодоношення становила від 1 до 2,5 бала;

3 група (клони із стабільно низькою інтенсивністю плодоношення) - клони, які впродовж 9-10 років із 15 (60\% випадків) характеризувалися середньою інтенсивністю плодоношення, менше ніж 1 бал. Тобто групи 2 і 3 було об'єднано в одну групу (№ 2), а групі 4 присвоєно №3:

Результати досліджень. Для перевіряння запропонованого раніше підходу до розподілу клонів на групи за інтенсивністю плодоношення (Los, 2008) здійснено попарне порівняння за t-критерієм середніх показників інтенсивності цвітіння і плодоношення груп клонів за роками (табл. 2).

Отже, за інтенсивністю цвітіння між групами 1 i 2 різниця між їх середніми показниками значуща лише у 4 випадках (роках), між групами 2 і 3 - у 8 випадках і між групами 1 і 3 - у 12 випадках 3 18. За інтенсивністю плодоношення різниці між групами 1 i 2 та 2 і 3 підтверджені статистично в $50 \%$ випадків, а між групами 1 і 3 - у $78 \%$ випадків (див. табл. 2). Варто зазначити, що різниця між групами була мінімальною в неврожайні роки, які характеризувалися несприятливими погодними умовами і тим, що показники усіх клонів усіх груп наближалися до нуля. Такими роками в період досліджень були 2007, 2009, 2011 і 2014 pp. Отже, закономірності, виявлені раніше у період до 2006 р., підтвердилися і у наступні 10 років, тому в основу подальшого аналізу репродуктивних особливостей клонів покладено саме таке їх групування.

Порівнюючи динаміку середніх показників інтенсивності цвітіння та плодоношення всіх представлених клонів дуба звичайного на КНП у Південному і Кочетоцькому лісництвах, 3'ясовано, що роки слабкого і рясного цвітіння на різних КНП збігаються (рис. 3). У деякі роки, особливо у врожайні, показники на КНП у Кочетоцькому лісництві були дещо вищими, ніж на КНП у Південному лісництві. Поясненням таких відмінностей можуть бути багатші грунтові умови КНП у Кочетоцькому лісництві.

Облік інтенсивності репродукції нещеплених дерев здійснювали з 2003 р. на КНП у Кочетоцькому лісництві і з 2009 р. у Південному. Порівняння середніх показників клонів і нещеплених дерев на обох КНП зображено на рис. 4. Отже, на КНП у Кочетоцькому лісництві впродовж усього 14-річного періоду показники інтенсивності цвітіння i плодоношення клонів були помітно вищими, ніж нещеплених дерев. При цьому, у період з 2003 по 2009 pp. різниця становила 4,2-9,1 раза, а у наступні 7 років зменшилася до 1,4-2,4 раза. Поясненням таких змін може бути збільшення віку дерев. Можна припустити, що після досягнення нещепленими деревами віку 25 років, інтенсивність їх цвітіння та плодоношення збільшується майже вдвічі. 
Таблиия 2

Істотність різниць за т-критерієм між середніми показниками цвітіння

і плодоношення груп клонів дуба звичайного, представлених на КНП у Південному лісництві

\begin{tabular}{ccccccc}
\hline & \multicolumn{3}{c}{ Інтенсивність } & \multicolumn{3}{c}{ Інтенсивність } \\
Рік & цвітіння & \multicolumn{2}{c}{ плодоношення } \\
\cline { 2 - 7 } & $1-2$ & $2-3$ & $1-3$ & $1-2$ & $2-3$ & $1-3$ \\
& гупп & гуп & груп & гуп & груп & груп \\
\hline 1999 & 1,27 & $\mathbf{2 , 0 4 *}$ & $\mathbf{3 , 2 2 *}$ & 0,82 & $\mathbf{2 , 0 2 *}$ & $\mathbf{2 , 0 6 *}$ \\
2000 & $2,05 *$ & 1,77 & $\mathbf{3 , 7 3 * *}$ & $\mathbf{2 , 0 4 *}$ & 1,13 & $\mathbf{2 , 4 4 *}$ \\
2001 & 0,60 & $\mathbf{3 , 4 5 * *}$ & $\mathbf{3 , 4 8 * *}$ & 1,90 & $\mathbf{4 , 8 0 * *}$ & $\mathbf{4 , 9 6 * *}$ \\
2002 & 1,25 & $\mathbf{3 , 6 7 * *}$ & $\mathbf{4 , 2 3 * *}$ & 1,70 & $\mathbf{2 , 5 1 *}$ & $\mathbf{3 , 3 6 * *}$ \\
2003 & 2,67 & $-0,70$ & 1,47 & $\mathbf{2 , 5 3 *}$ & $\mathbf{2 , 1 2 *}$ & $\mathbf{4 , 0 8 * *}$ \\
2004 & $-0,04$ & $\mathbf{2 , 7 0 *}$ & 2,16 & $\mathbf{3 , 2 8 * *}$ & 1,39 & $\mathbf{4 , 9 2 * *}$ \\
2005 & 1,34 & $\mathbf{2 , 0 2 *}$ & $\mathbf{3 , 8 5 * *}$ & $\mathbf{3 , 1 8 *}$ & 1,09 & $\mathbf{4 , 2 9 * *}$ \\
2006 & 0,16 & $\mathbf{2 , 0 4 *}$ & 1,98 & $\mathbf{2 , 0 3 *}$ & 0,62 & $\mathbf{3 , 5 0 * *}$ \\
2007 & 0,17 & 1,08 & 1,53 & 1,12 & $\mathbf{3 , 4 2 * *}$ & 1,69 \\
2008 & 1,96 & 1,44 & $\mathbf{3 , 0 9 *}$ & 3,81 & 0,88 & $4,09 * *$ \\
2009 & 0,81 & 1,14 & 1,69 & 1,57 & 1,36 & $\mathbf{2 , 1 6 *}$ \\
2010 & 1,08 & $\mathbf{2 , 0 7 *}$ & $\mathbf{2 , 6 1 *}$ & $\mathbf{3 , 8 5 * *}$ & $\mathbf{2 , 4 4 *}$ & $\mathbf{5 , 1 6 * *}$ \\
2011 & 0,75 & 0,19 & 0,90 & 0,70 & 0,65 & 1,72 \\
2012 & 1,77 & 1,91 & $\mathbf{2 , 9 5 *}$ & 4,24 & $\mathbf{2 , 6 2 *}$ & $\mathbf{6 , 1 8 * *}$ \\
2013 & 1,03 & $\mathbf{2 , 6 9 *}$ & $\mathbf{5 , 5 0 * *}$ & 1,45 & $\mathbf{2 , 7 5 *}$ & $\mathbf{4 , 7 0 * *}$ \\
2014 & 0,69 & $-1,49$ & $-0,64$ & 0,69 & 1,35 & 1,52 \\
2015 & $\mathbf{2 , 0 2 *}$ & 1,52 & $\mathbf{2 , 9 1 *}$ & $\mathbf{2 , 3 0 *}$ & $\mathbf{2 , 3 3 *}$ & $\mathbf{3 , 2 2 * *}$ \\
2016 & 0,17 & 0,69 & 0,84 & $-1,00$ & 1,00 & 0,00 \\
\hline & $*$ & & &
\end{tabular}

Примітка: 1 * значущість на $5 \%$ рівні

2 ** значущість на $1 \%$ рівні

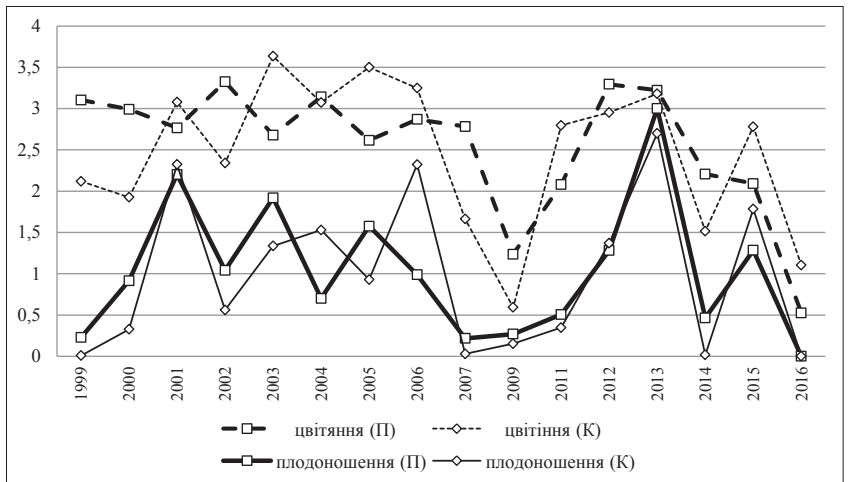

Рис. 3. Динаміка середніх показників інтенсивності цвітіння та плодоношення клонів дуба звичайного на КНП у Південному (П) і Кочетоцькому (К) лісництвах

Порівняння показників інтенсивності цвітіння і плодоношення клонів та нещеплених дерев на КНП у Південному лісництві також показало значні переваги перших (рис. 5). Різниця становила від 2,5 до 3,7 раза - для цвітіння і від 3,2 до 8,6 раза - для плодоношення у 30-37-річному віці.
Розглядаючи динаміку інтенсивності репродукції за групами клонів на КНП у Кочетоцькому і Південному лісництвах, яку графічно представлено на рис. 6, зазначимо, що загальні тенденції для обох КНП і всіх груп клонів подібні. За увесь 18-річний період спостережень було лише 2 роки 3 дуже низькою інтенсивністю цвітіння - 2007 і 2014 рр., коли навіть показники клонів, які інтенсивно плодоносять, не перевищували 1,5 бала, для клонів 2 групи становили близько 1 бала, а слабоврожайних - 0,5 бала. Відносно рясним цвітінням за зазначений період вирізнялися 6 років $(2000,2002,2008,2010$, 2012 і 2013), коли середні показники клонів 1 групи перевищували 3,5 бала, 2 групи - 3,0 бала, а 3 групи $-2,0$ бала. При цьому показники нещеплених дерев змінювалися у межах 0,5-2 балів.

Аналізуючи динаміку інтенсивності плодоношення (рис.7), виявлено певну синхронність між показниками двох КНП за всіма групами клонів. Протягом усього періоду спостережень роки з рясним або середнім урожаєм чергувалися 3 роками його практичної відсутності. Дуже низьке плодоношення зафіксовано у 2007 і 2014 рр., а також у 1999, 2009 і 2011 рр., коли показники всіх клонів незалежно від групи були на рівні 0,5-1,0 бали. Рясний урожай виявлено у 2013 р., добрий і середній - у 2001, 2003, 2005, 2010 i 2015 pp.

Амплітуда коливань показників у неврожайні і врожайні роки найбільша у клонів, які інтенсивно плодоносять. Клони, що слабо плодоносять, та нещеплених дерев перебувають на одному рівні і характеризуються найменшими показниками. Отже, за результатами багаторічних спостережень емпірично доведено, що використання для створення КНП дуба звичайного клонів 3 низькою інтенсивністю репродукції має такий самий ефект, як використання нещеплених рослин. Недоцільним $є$ також і відбір таких плюсових дерев.

Високі витрати на вирощування щепленого садивного матеріалу, створення та експлуатацію КНП дуба звичайного можуть окупитися лише рясними урожаями жолудів. Під час створення КНП у 70-х роках вважали, що для цього достатньо забезпечити щепам добрі умови живлення й освітлення для їх задовільного та рясного плодоношення. Нині стало очевидним, що навіть дотримання всіх технологічних вимог до створення КНП (добре освітлення крон, сприятливі грунтові умови, належні догляд й боротьба зі шкідниками і хворобами) не дасть бажаного ефекту, якщо представлені на них клони мають низьку репродуктивну спроможність. КНП доцільно створювати лише із клонів, що характеризуються середнім і рясним плодоношенням. При цьому перевагу доцільно надавати деревам з рясним плодоношенням.

Під час відбору плюсових дерев обов'язково потрібно враховувати їхню репродуктивну спроможність. Визначити цей показник можливо і бажано, насамперед, за наявністю жолудів у кроні. Але в такому разі виникають часові обмеження, які передбачають проведення відбору впродовж серпнявересня. 


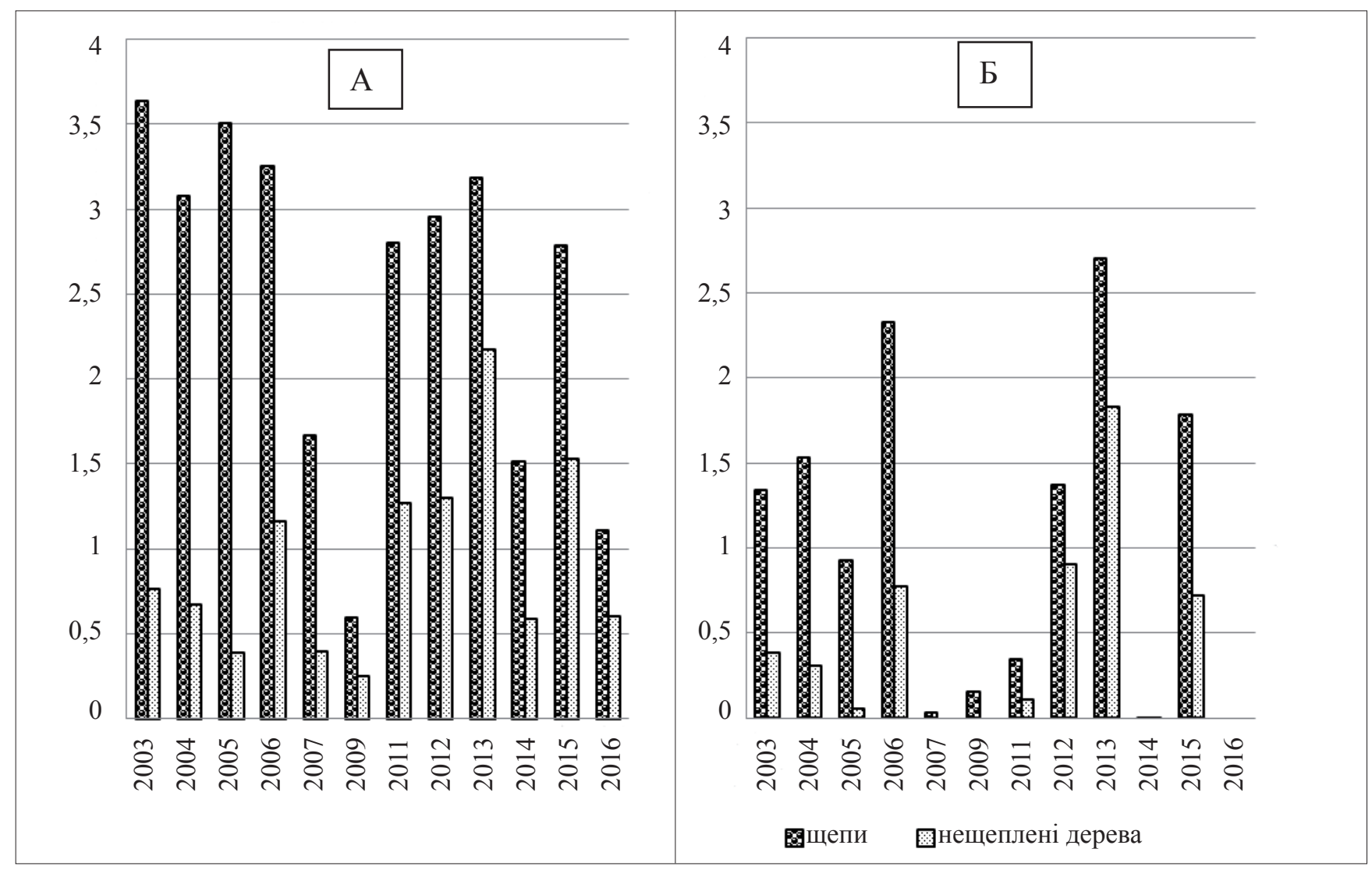

Рис. 4. Динаміка середніх показників інтенсивності цвітіння (А) і плодоношення (Б) щеплених і нещеплених дерев на КНП у Кочетоцькому лісництві впродовж 2003-2016 pp.

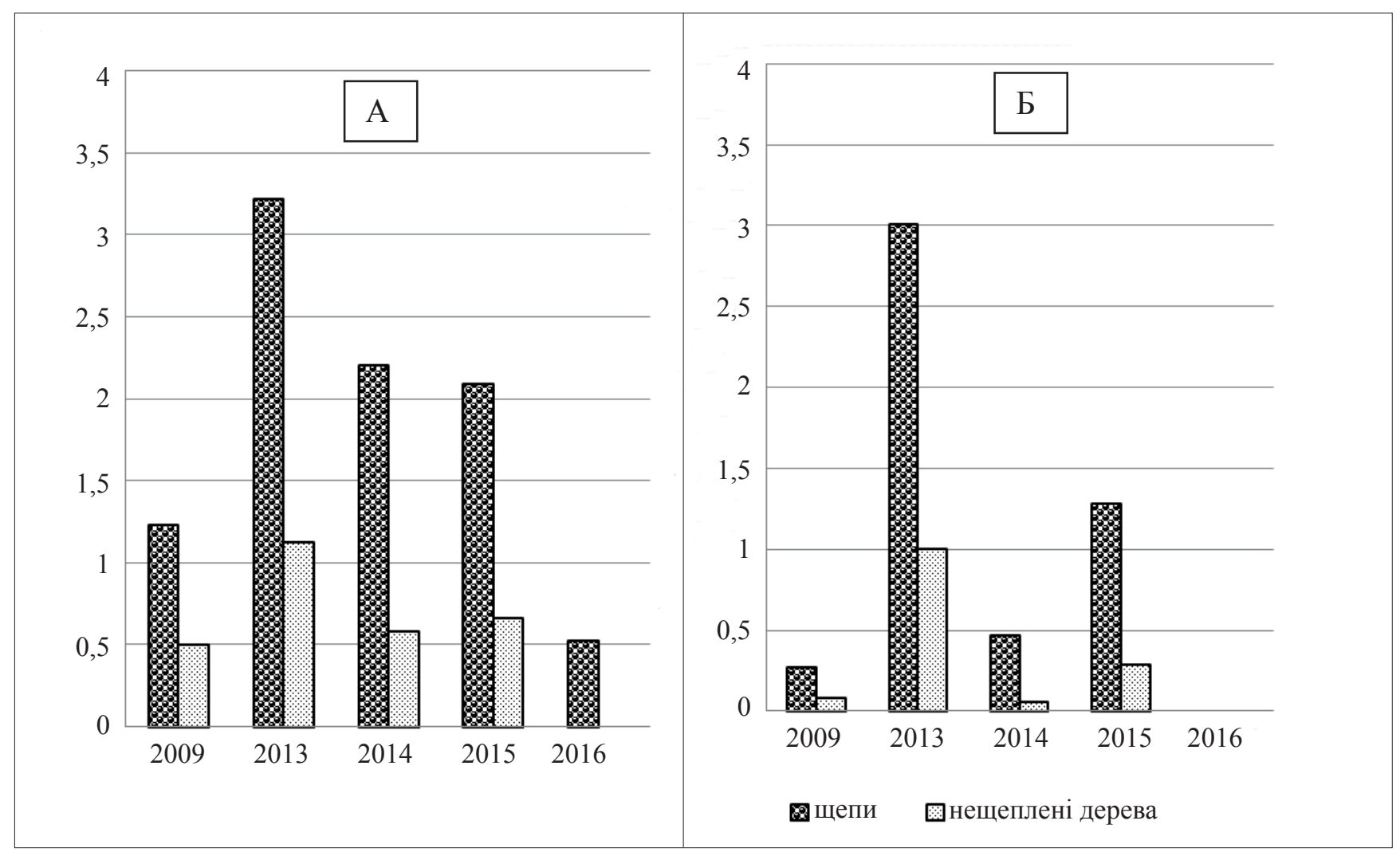

Рис. 5. Динаміка середніх показників інтенсивності цвітіння (А) і плодоношення (Б) щеплених і нещеплених дерев на КНП у Південному лісництві впродовж 2009-2016 pp. 

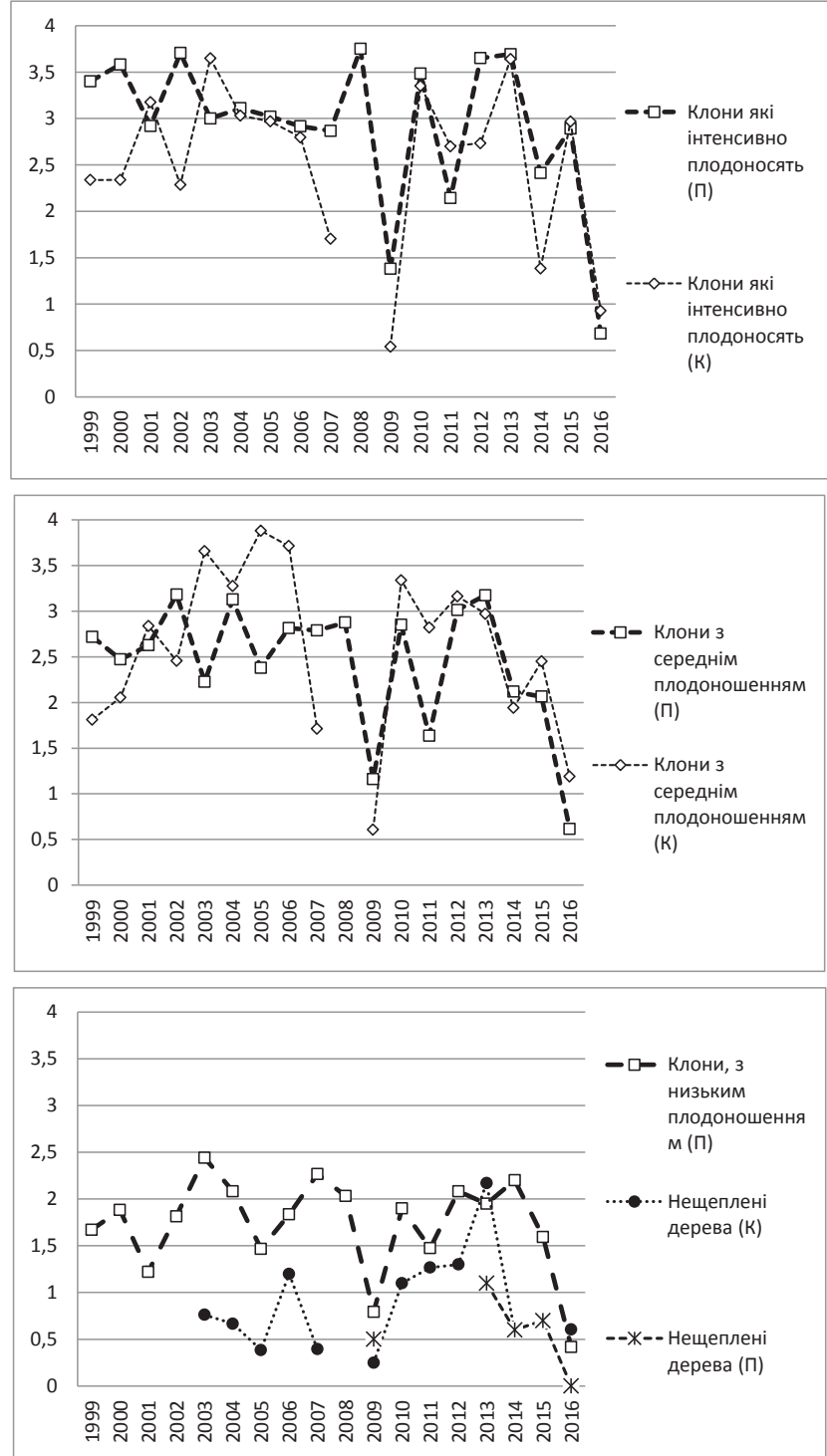

Рис. 6. Динаміка середніх показників інтенсивності цвітіння (бали) за групами клонів на КНП

у Південному (П) та Кочетоцькому (К) лісництвах упродовж 1999-2016 pp.

3 іншого боку, з нашого досвіду, визначити репродуктивну спроможність дерева можливо також за наявністю цьогорічних жолудів або плисок під його кроною в пізній осінній період, а у літній період - за наявністю зав'язі під кронами або минулорічних жолудів у підстилці. Такі спостереження бажано проводити впродовж трьох років. За відсутності ознак репродукції потрібно відмовитися від відбору такого дерева.

Висновки. За період 18-річних спостережень за КНП дуба звичайного у Харківській обл. у 78\% випадків виявлено значущі відмінності між середніми показниками груп клонів 3 різною інтенсивністю плодоношення. Різниця між групами мінімальна в неврожайні роки і максимальна - у роки 3 рясним урожаєм.

Роки слабкого і рясного цвітіння на різних КНП дуба звичайного збігаються. В окремі роки інтенсивність цвітіння і плодоношення на КНП у Кочетоцькому лісництві є дещо вищою, ніж на КНП у
Південному лісництві, що можна пояснити багатшими грунтовими умовами першої плантації.
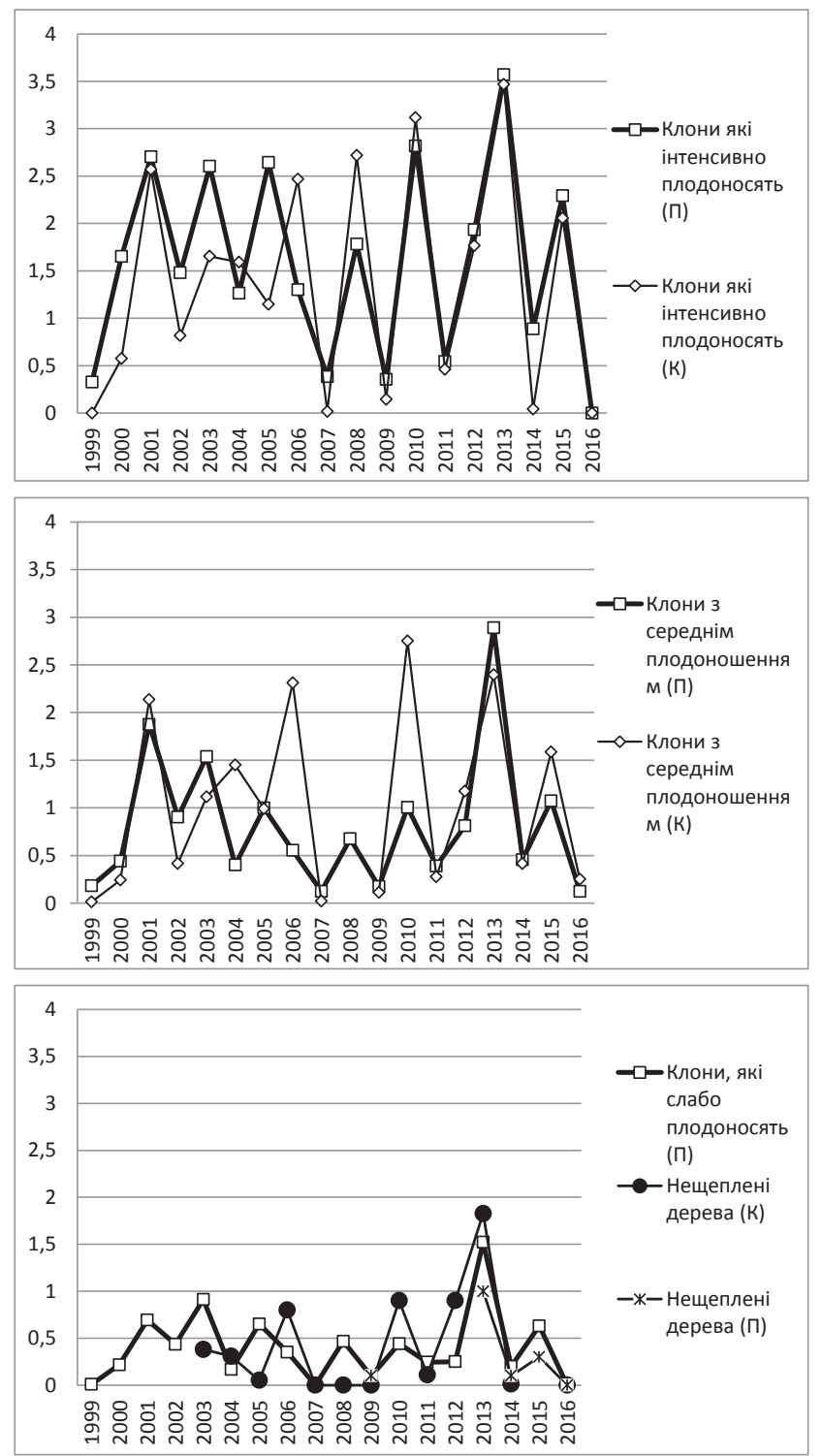

Рис. 7. Динаміка середніх показників інтенсивності плодоношення (бали) за групами клонів на КНП у Південному (П) та Кочетоцькому (К) лісництвах упродовж 1999-2016 pp.

Кількісні показники інтенсивності цвітіння і плодоношення на досліджених КНП були суттєво вищими у групи клонів з інтенсивним і середнім плодоношенням, ніж у нещеплених дерев. При цьому, у віці до 25 років ця різниця становила 4,2-9,1 раза, а після 25-річного віку зменшилася до 1,4-2,4 раза завдяки покращенню репродукції нещеплених дерев.

Показники репродукції клонів, що слабо плодоносять, та нещеплених дерев перебувають на подібному низькому рівні. 3 огляду на це використання для створення виробничих КНП дуба звичайного дерев $з$ низькою інтенсивністю репродукції дає такий самий ефект, як і використання нещеплених рослин. Доцільно створювати КНП лише із клонів, які характеризуються середнім і рясним плодоношенням, при цьому перевагу доцільно надавати останнім. 
Для плюсових біотипів дуба звичайного інтенсивність репродукції $є$ не менш важливим показником, ніж прямизна стовбура та швидкість росту, а тому цей показник має бути кількісно ідентифікований і введений до переліку критеріїв відбору плюсових дерев. Потрібно відбирати плюсові дерева із середнім або рясним плодоношенням.

\section{Бібліографічні посилання}

Belous, V.I. (1980). Fructification and crops protection on oak clonal seed orchards. Selection, genetics and seed-growing of tree species as a basis for creating highly productive forests, Part 2, 377-381. Moscow: USSR: CC of USSR on forestry (in Russian).

Bilous, V.I. (2004). Why unsuccessfully fruiting the clonal seed orchards. Forest and Hunting magazine, 1, 13 (in Ukrainian).

Fennytch, V. S., Turys, E. V. (2006). Results of flowering and fruiting of clonal forest-seed plantations in Zakarpattia. Forestry, paper and woodworking industry, 13, 219-223 (in Ukrainian).

Guidelines for forest seed growing (1983). Kharkiv: Ukrainian research institute of forestry and forest melioration (in Ukrainian).

Improving seed production from forest seed orchards in the Baltic Sea region countries - establishment, management, flowering stimulation and protection (2013). Latvia: Silava.

IUFRO Seed orchard conference (2017). Bålsta, Sweden: Skogforsk.

Kima, H.T., Kanga, J.W., Leeb, W.Y., Hanb, S. U,, Parka, E. J. (2016). Estimation of acorn production capacity using growth characteristics of Quercus acutissima in a clonal seed orchard. Forest Science and Technology, 12 (1), 51-54.

Los, S.A. (2008). Analysis of 15-years dynamics of flowering and fruiting intensity of English oak clones in the north-east of Ukraine. Forestry and forest melioration, issue 113, 42-50 (in Ukrainian).

Los, S.A. (2010) Intensity of English oak clones reproduction, depending on their phenological affiliation. Science of the forest in the XXI century: Materials of the international scientific and practical conference. 235-238. Gomel, Belarus: Institute of Forest of the National Academy of Sciences of Belarus (in Russian).

Los, S.A., Tereshchenko, L. I., Gayda, Yu. I., Ustimenko, P.M., Yatsyk, R.M., Chernyavsky M. V., ... Jurova, P. 1. State of forest genetic resources in Ukraine. Kharkiv: Planeta-print (in English and Ukrainian).

McKeand, S. (2017). New challenges for seed orchard management of Loblolly Pine in the southern US.

Oweviev. Forest Tree Breeding Center. (2013): [Springer Link version] - Retrieved from: http://www.ffpri. affrc.go.jp/ftbc/en/documents/ h22_centerpamphlet_ english_a4.pdf

Program for the seed growing development to 20102015 (2010). Kyiv: State Forestry Committee (in Ukrainian).
Pyatnitsky, S.S. (1951). On the question of the socalled periodicity of oak fruiting, Forestry, 8, 70-75 (in Russian).

Review of the Swedish tree breeding programme (2011). Sweden: Skogforsk.

Yurkuv, Z. M., Neyko, I. S. (2017). Prospects of increasing the productivity of forests of Ukraine by methods of forestry selection and forest seeds growing. Scientific bulletin of Vinnytsia National Agrarian University, 6 (2), 25-34 (in Ukrainian).

Zhenxiang, H. (2017). Extremely high seed yields of a new seed orchard concept (NSOC) of Chinese Fir (Cunninghamia lanceolata): innovation, techniques and management. IUFRO Seed orchard conference. 21-22. Bålsta, Sweden: Skogforsk.

\section{Динамика репродуктивных процессов на клоновых семенных плантациях дуба обыкновенного (Quercus robur L.) в Левобережной Лесостепи Украины}

\author{
Лось C. А. ${ }^{1}$
}

Клоновые семенные плантации (КСП), которые обеспечивают лесохозяйственное производство улучшенными или элитными семенами, в настоящее время остаются важнейшими объектами лесосеменной базы во многих странах мира. Важнейшим показателем, характеризующим их эффективность, является интенсивность репродукции представленных на них клонов.

Объект исследования - эффективность использования клоновых семенных плантаций. Предмет исследования - репродукция клонов на клоновых семенных плантациях дуба обыкновенного (Quercus robur L.).

Цель исследований заключалась в выявлении особенностей репродукции дуба обычного на КСП на основе сравнения показателей интенсивности цветения и плодоношения разных клонов, их групп и КСП на Северо-Востоке Украины.

Рассмотрена динамика интенсивности цветения и плодоношения клонов дуба обыкновенного и их групп на двух КНП в Харьковской области, созданных посадкой привитых саженцев с закрытой корневой системой с размещением привитых растений $5 \times 10$ м. Интенсивность цветения и плодоношения клонов определены визуально по шестибальной шкале.

Подтверждена целесообразность использования предложенного ранее подхода к распределению клонов на группы по интенсивности плодоношения. Выявлены значимые различия между средними по-

\footnotetext{
Лось Светлана Анатольевна - член-корреспондент Лесной академии наук Украины, кандидат сельскохозяйственных наук, заведующий лабораторией селекции. Украинский научноисследовательский институт лесного хозяйства и агролесомелиорации им. М. Высоцкого, ул. Пушкинская, 86, г. Харьков, 61024, Украина. Тел.: 057-707-80-77, +38-097-138-97-92. E-mail: svitlana_los@ukr.net
} 
казателями групп клонов с разной интенсивностью плодоношения, при этом разница между группами минимальная в неурожайные годы и максимальная - в годы с обильным урожаем. Интенсивность цветения и плодоношения клонов с интенсивным и средним плодоношением на обеих КСП в течение 18 лет наблюдений были заметно выше, чем клонов, которые слабо плодоносят и непривитых деревьев.

Сравнение средних показателей клонов и непривитых деревьев на двух КСП показало, что интенсивность цветения и плодоношения клонов были заметно выше, чем непривитых деревьев.

Выявлено синхронность лет слабого и обильного цветения на различных КСП Харьковской области. В некоторых случаях, показатели на КСП на богатых почвах были выше.

Подчеркнуто, что для дуба обычного интенсивность репродукции является не менее важным показателем, чем прямизна ствола и интенсивность роста. Этот показатель должен быть включен в перечень критериев для отбора плюсовых деревьев. Отмечено, что использование для создания КСП дуба обыкновенного клонов с низкой интенсивностью репродукции имеет такой же эффект, как использование непривитых деревьев. Целесообразно создавать КСП только из клонов, характеризующихся средним и обильным плодоношением, при этом предпочтение следует отдавать последним.

При отборе плюсовых деревьев дуба обыкновенного интенсивность репродукции является не менее важным показателем, чем прямизна ствола и скорость роста, поэтому данный показатель должен быть включен в перечень критериев отбора плюсовых деревьев. Следует отбирать плюсовые деревья со средним или обильным плодоношением.

Ключевые слова: интенсивность цветения и плодоношения, репродукция, репродуктивная способность, клоны, плюсовые деревья, клоновые семенные плантации, Quercus robur L.

\section{Dynamics of reproductive processes on English oak (Quercus robur L.) clonal seed orchards in the left-bank Forest-Steppe of Ukraine}

\section{S. Los ${ }^{1}$}

Clonal seed orchards (CSO), which provide forestry production with improved or elite seeds, currently are the most important objects of the seed growing base in

Svitlana Los - Corresponding Member of the Forestry Academy of Sciences of Ukraine, PhD in Agricultural Sciences, Head of laboratory of forest tree breeding of Ukrainian Research Institute of Forestry and Forest Melioration named after G. M. Vysotsky, Pushkinska str., 86, Kharkiv, 61024, Ukraine. Тел.: 057-707-80-77, +38-097-138-97-92. E-mail: svitlana_los@ukr.net many countries of the world. The most important indicator, characterizing their effectiveness, is the reproduction intensity of represented on them clones.

The object of the study is the effectiveness of the clonal seed orchards use. The subject of the study is reproduction of clones on clonal seed orchards of English oak (Quercus robur L.).

The research was aimed to identify the peculiarities of English oak reproduction in the CSO on the basis of comparison of flowering and fruiting intensity of different clones, their groups and CSO in the Northeast of Ukraine.

The flowering and fruiting intensity dynamics of oak clones and their groups on two CSO in the Kharkiv region, created by planting grafted seedlings with a closed root system with the arrangement of grafted plants $5 \times 10 \mathrm{~m}$, were studied. The flowering and fruiting intensity of clones were evaluated visually by a sixpoint scale.

The feasibility of using the previously proposed approach to the clones division into groups by the fruiting intensity was confirmed. Significant differences between the average indices of clone groups with different fruiting intensities were identified, while the difference between groups is minimal in lean years and the maximum in years with abundant harvest. The flowering and fruiting intensity of clones with intensive and medium fruit bearing on both CSO during 18 years of observation were noticeably higher than those that poorly bear fruit and ungrafted trees.

Comparison of the clones and ungrafted trees by average indices on two CSO showed that the flowering and fruiting intensity of the clones was significantly higher than that of ungrafted trees.

The synchronism of the years of weak and abundant flowering in different CSOs of Kharkiv region has been revealed.

It is emphasized that for English oak reproduction intensity is no less important than the stem straightness and the growth intensity. This indicator should be included in the list of criteria for plus trees selection. It is noted that English oak clones with low reproduction intensity using to CSO creations has the same effect as using of ungrafted trees. It is recommended to create CSO only from clones characterized by medium and abundant fruiting, while preference should be given to the latter.

The reproductions intensity is no less important characteristic for the English oak plus trees selection than the trunk straightness and the growth rate, so this indicator should be included in the list of selection criteria for plus trees. The trees with medium or abundant fruit bearing should be selected as plus trees.

Key words: flowering and fruiting intensity, reproduction, reproductive capacity, clones, plus trees, clonal seed orchards, Quercus robur L. 